\title{
Visual surveys reveal high densities of large piscivores in shallow estuarine nurseries
}

\author{
Ronald Baker ${ }^{1,2, *}$, Marcus Sheaves ${ }^{1}$ \\ ${ }^{1}$ School of Marine and Tropical Biology, James Cook University, Townsville, Queensland 4811, Australia \\ ${ }^{2}$ Coastal CRC, Indooroopilly Sciences Centre, 80 Meiers Rd, Indooroopilly, Queensland 4068, Australia
}

\begin{abstract}
Shallow estuarine nurseries are widely believed to provide juvenile fishes with refuge from predation due to the low numbers of piscivorous fishes. Observations during several years of fieldwork in northeastern Australia indicate that the assemblage of large ( $\geq 100 \mathrm{~mm})$ piscivorous fishes within shallow tropical estuarine nurseries may have been considerably underestimated by previous sampling efforts. This study utilised visual surveys of shallow sandy shorelines in the lower reaches of estuaries to estimate the abundance of large piscivores. Flathead (Platycephalus spp., Platycephalidae) were the only large piscivores sighted within transects. A total of 296 flathead between 100 and $600 \mathrm{~mm}$ TL were observed in waters between 0.02 and $0.62 \mathrm{~m}$ deep. The density of flathead observed during the present study $\left(0.04\right.$ ind. $\left.\mathrm{m}^{-2}\right)$ equated to 1 piscivore $\geq 100 \mathrm{~mm} \mathrm{TL}$ for every $10.5 \mathrm{~m}$ of shoreline surveyed, and far exceeds density estimates for large piscivores in shallow estuarine habitats elsewhere in the world. Furthermore, the estimated biomass of flathead $\left(11.56 \mathrm{~g} \mathrm{~m}^{-2}\right)$ was equivalent to comparable biomass estimates of entire fish assemblages from shallow estuarine habitats in other parts of the world. The densities and depth distribution of these large piscivores suggests that shallow water nurseries may not provide small fishes with the level of refuge from predation previously assumed.
\end{abstract}

KEY WORDS: Piscivory $\cdot$ Nursery $\cdot$ Refuge $\cdot$ Platycephalus $\cdot$ Visual census

\section{INTRODUCTION}

Shallow estuarine habitats around the world are considered to be valuable nurseries, because they are believed to provide abundant food and refuge from predation for small and juvenile fishes (e.g. Blaber \& Blaber 1980, McIvor \& Odum 1988, Ruiz et al. 1993, Laegdsgaard \& Johnson 1995, Beck et al. 2001). The refuge theory is based, in part, on reports of low abundances of piscivorous fishes within estuarine habitats (e.g. Shenker \& Dean 1979, Blaber 1980, Rozas \& Hackney 1983, Boesch \& Turner 1984, Paterson \& Whitfield 2000). The piscivore assemblage of shallow $(<1.5 \mathrm{~m})$ tropical estuarine habitats in northeastern Australia was recently found to be far more diverse and abundant than previously thought, with a large proportion of fishes that inhabit shallow estuarine waters being piscivorous to some degree (Baker \& Sheaves 2005). While this expanded view of the piscivore assemblage mainly incorporates previously overlooked small and occasional piscivores that prey on new recruits, observations during several years of fieldwork indicate that the assemblage of large piscivorous fishes within shallow tropical estuarine habitats are considerably underestimated.

Aspects of the use of shallow-water habitats by piscivorous fishes have been examined in temperate Australian estuarine systems (e.g. Hindell et al. 2000, 2001, Smith \& Hindell 2005), however these studies have focused mainly on structurally complex habitats such as seagrass beds and mangroves. The shallow water habitats utilised as nurseries in tropical northeastern Queensland are predominantly structurally simple and unvegetated. Fishes may gain access to mangrove 
forest habitats during larger high tides; however, for the majority of the time these habitats are inaccessible (Sheaves 2005). Although several species of seagrass occur lower in the intertidal and subtidal areas of the regions estuaries, these do not form extensive meadows common in other parts of the world (Coles et al. 1987, 1993, Hindell et al. 2000). The structural and faunal differences between tropical and temperate systems mean that processes such as habitat use and predation are likely to vary considerably between these systems (Smith \& Hindell 2005).

Platycephalus spp. (Platycephalidae, mainly P. fuscus, also $P$. endrachtensis [indicus] and $P$. arenarius) were the most abundant and commonly encountered primary piscivores in shallow $(<1.5 \mathrm{~m})$ waters of estuaries sampled with seine nets by Baker $\&$ Sheaves (2005). The diet of large $(\geq 100 \mathrm{~mm})$ flathead (Platycephalus spp.) in this region primarily consists of small and juvenile fishes that utilise shallow-water nursery habitats (Baker \& Sheaves 2005). However, large flathead are generally reported in relatively low abundances from similar habitats in this and other parts of the Indo-West Pacific (Blaber et al. 1989, Blaber \& Milton 1990, Haywood et al. 1998, Salini et al. 1998, Sheaves 2001). During the course of sampling 16 estuaries over several years, large flathead were regularly seen retreating from the shallow margins of sandbanks when spooked by the net operators or boat (authors' pers. obs.). It was clear that these relatively common, large, shallowwater specialist piscivores (Sheaves \& Molony 2000, Baker \& Sheaves 2005) were underrepresented in shallow waters by previous sampling efforts. The aim of this article was to determine the density of large piscivores $(\geq 100 \mathrm{~mm})$ in shallow water habitats.

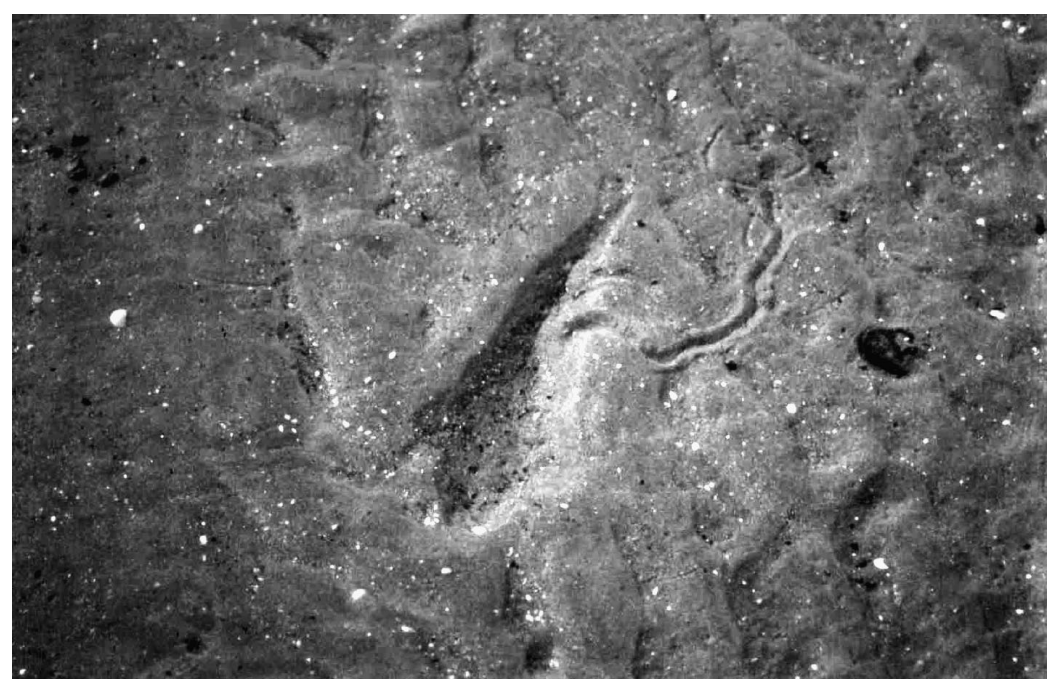

Fig. 1. Platycephalus sp. Imprint or 'lie' of a flathead left on an intertidal sandbank

\section{MATERIALS AND METHODS}

Study sites and field methods. The density of large $(\geq 100 \mathrm{~mm})$ piscivores in shallow tropical estuarine waters was estimated by visual census. Between July 2003 and August 2004, 39 transects were surveyed by walking the shore line along shallow, unvegetated sand banks in the lower reaches $(<5 \mathrm{~km})$ of 4 estuaries in northeastern Queensland, Australia (Victoria Creek $\mathrm{n}=12$, Herbert River $\mathrm{n}=20$, Seymour River $\mathrm{n}=6$, and Ross River $n=1$ ). A map of the study sites can be found in Baker \& Sheaves (2005). Transects were between 10 and $1300 \mathrm{~m}$ long (mean $\pm \mathrm{SE}=232 \pm 33 \mathrm{~m}$, total $9036 \mathrm{~m}$ ) and between 1 and $5 \mathrm{~m}$ wide (35 were $3 \mathrm{~m}$ wide) depending on the topography of the shore and visibility conditions. The methodology was primarily designed to measure the density of large $(\geq 100 \mathrm{~mm})$ flathead (Platycephalus spp.), and during the course of the study no other large piscivores were sighted within the transects.

Flathead bury themselves into the substrate from where they ambush passing prey (Douglas \& Lanzing 1981). Their behaviour makes them particularly amenable to visual census in shallow waters. They generally remain buried until the observer approaches within a few metres, and upon spooking they retreat into deeper water in a direction approximately perpendicular to the shore. Retreating flathead leave an imprint or 'lie' in the substrate (Fig. 1). Occasionally, imprints of the pectoral and caudal fins are visible within the lies, and observations of these indicate that the total length of the flathead can be accurately estimated from the length of the lie. Most transects were censused a second time, immediately following the initial census, by walking back along the shoreline just surveyed. The second census revealed only 2 flathead during the entire study, indicating that spooked flathead rarely returned to the transect within the time frame of the initial census. Additionally, the within-transect density patterns observed provide no evidence of the observer 'herding' flathead along the shore. Consequently, the probability of an individual flathead being observed and counted more than once during any census was low.

Density was estimated by counting the number of individuals observed within each transect. The distance of each individual along a transect was measured $( \pm 1 \mathrm{~m})$ using a distance measuring wheel. The size of individual flathead was measured as the 
length of the lie $( \pm 2.5 \mathrm{~cm})$ left by fish observed retreating into deeper water, and the depth at which the flathead was stationed was measured as the depth at the head end of the lie $( \pm 1 \mathrm{~cm})$. When a flathead was observed near the outer edge of the predefined transect (see below for determination of transect widths) the distance of the lie from the shore was measured. Only individuals confirmed to have been stationed within the predefined transect were recorded. Only lies left by observed fish were measured. Lies left by individuals that were not observed were not measured because an actively feeding individual could leave multiple lies within an area.

Particular shoreline characteristics and conditions are required to successfully conduct visual surveys within estuaries. The water must be clear enough to see the bottom beyond the outer edge of the transect. Rough weather, wind, large tides and muddy substrate create turbid water or ruffle the water surface, making many sites or occasions unsuitable for visual surveys. The sediment within the transect must retain imprints or lies that are clear enough to gain accurate length estimates. Cloud cover and the position of the sun also influence visibility within the transect. Compounding visibility issues, the presence of estuarine crocodiles in many of the estuaries in the region made entering the water to measure size and depth of flathead too dangerous at many locations where flathead were regularly observed.

In an effort to ensure reliable density estimates, transect widths were set prior to the commencement of each survey based on the visibility conditions at the beginning of the transect. Widths were set such that a flathead that was spooked at least $1 \mathrm{~m}$ beyond the outer edge would be clearly visible, ensuring that all fish spooked within the defined transect would be observed. However, variable visibility along the length of many transects, caused by changes in topography, turbidity, wind direction or cloud cover, meant that density estimates from some transects were considered unreliable due to poor visibility. For each transect surveyed, visibility was categorised as either 'good' or 'poor'. 'Good' indicated that visibility was consistent along the length of the transect, such that the observer was confident of spooking and sighting fish at least $1 \mathrm{~m}$ beyond the outer edge for the entire length of the transect. 'Poor' visibility meant that because of variable visibility conditions along the transect, some spooked fish might not be sighted or that fish within some sections of the transect may not have been spooked by the passing observer.

Analysis. Only data from the transects classified as having good visibility were included in analyses. The density of flathead (individuals $\mathrm{m}^{-2}$ ) within each transect was calculated. Biomass estimates were derived from the length-weight relationship of Platycephalus fuscus 100 to $442 \mathrm{~mm}$ TL ( $=75$ ), the most abundant Platycephalus spp. sampled from these habitats by Baker \& Sheaves (2005). The length-weight relationship is described by the equation: weight $(\mathrm{g})=$ $0.0000027 \times$ length $(\mathrm{mm})^{3.1421}$. This equation was used to estimate the weight of all flathead observed, including the 29 individuals $>442 \mathrm{~mm}$ TL. Although it is potentially inaccurate to extrapolate estimates beyond the range of data used to calculate the length-weight relationship, the high $\mathrm{r}^{2}$ (0.997) for the relationship indicates that the weight estimates for those individuals up to the maximum length recorded (600 mm TL) should be reasonably accurate.

Because flathead appeared to form aggregations, the $10 \mathrm{~m}$ maximum density was calculated (the maximum density of flathead within a $10 \mathrm{~m}$ long section of the transect). The null hypothesis that flathead were randomly distributed within the transects (i.e. not aggregated) was tested using a Chi-squared goodness-of-fit test (Zar 1999). To achieve this, each transect was treated as a series of $3 \times 3 \mathrm{~m}$ quadrats. The observed frequency distribution of the number of flathead per quadrat was compared to the expected frequency given a Poisson (random) distribution. To determine any size-related pattern in the minimum water depth occupied by flathead, the slope of the lower boundary of the relationship between flathead size and water depth was estimated using quantile regression (Scharf et al. 1998). The significance of the slope estimate was determined using the bootstrap resampling technique of Gould (1992). The relative abundance (\% of total) of flathead occupying each $0.1 \mathrm{~m}$ depth zone within each transect was calculated. To determine the depth distribution of flathead within transects, the average relative abundance in each depth zone was calculated for the transects with good visibility in which 10 or more individuals were sighted ( $\mathrm{n}=9$ transects).

\section{RESULTS}

A total of 296 flathead $\geq 100 \mathrm{~mm}$ TL were observed. Of these, 281 were sighted in the 14 transects classified as having good visibility. Only these 14 transects were used to estimate densities and biomass, and these transects were each $3 \mathrm{~m}$ wide. No large individuals $(>100 \mathrm{~mm})$ of other piscivorous taxa were sighted in any transect.

Up to 71 flathead were sighted within a single transect (Fig. 2c). The average density $( \pm$ SE) was $0.0428 \pm$ $0.0139 \mathrm{~m}^{-2}$ (range 0.0027 to $0.1972 \mathrm{~m}^{-2}$ ) (Table 1). This equates to an average of 1 flathead $\geq 100 \mathrm{~mm}$ TL for every $10.5 \mathrm{~m}$ of shoreline surveyed. Average biomass $( \pm \mathrm{SE})$ was $11.56 \pm 3.72 \mathrm{~g} \mathrm{~m}^{-2}$, ranging from 0.12 to $46.16 \mathrm{~g} \mathrm{~m}^{-2}$. 
Flathead were significantly aggregated $\left(\chi^{2}[2 \mathrm{df}]=\right.$ 448.8, p < 0.001, variance:mean = 3.3:1). Larger aggregations generally spanned much of the observed depth range within each transect (Fig. 2). We found $\geq 5$ individuals within $10 \mathrm{~m}$ sections in 9 transects (e.g. Fig. 2a), and $10 \mathrm{~m}$ maximum densities were up to $0.8667 \mathrm{~m}^{-2}$ (26 fish within a $10 \times 3 \mathrm{~m}$ section of shoreline) (Table 1 , Fig. 2c). Often, more than 1 aggregation of $\geq 5$ individuals would be present within a transect (e.g. Fig. 2b,c).
Some large flathead were observed in very shallow water (Fig. 3). The flathead sighted ranged in length from 100 to $600 \mathrm{~mm}$ TL and were stationed in waters between 0.02 and 0.62 m deep (Table 1, Fig. 3). Although there is some indication of smaller fish entering slightly shallower waters than larger individuals (Fig. 3), the slopes of quantile regressions describing the lower boundary of the flathead size-water depth distribution were not significant for any of the 1st, 5th or 10th quan-
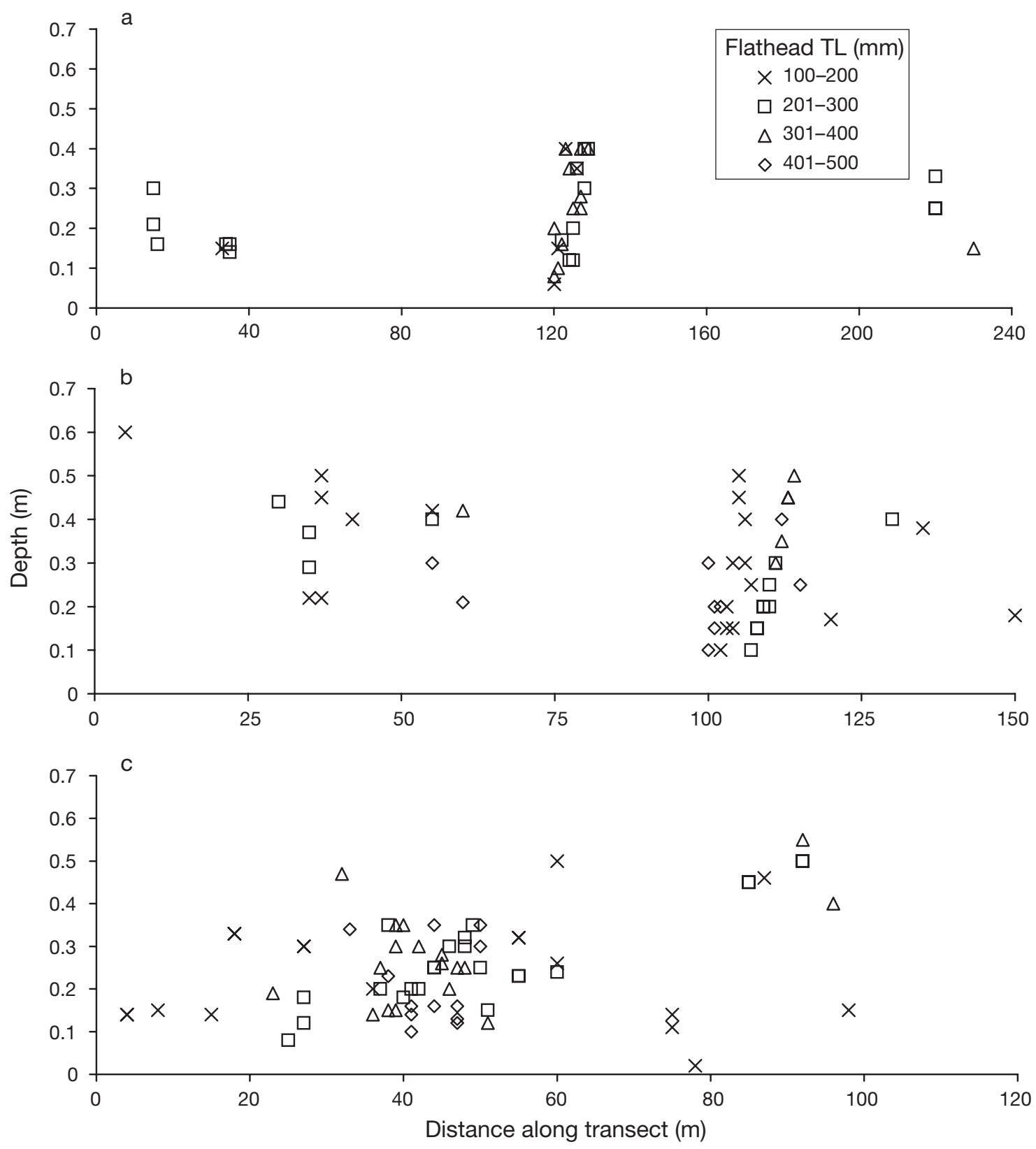

Fig. 2. Platycephalus spp. Examples of the size structure and depth distribution of flathead observed during visual census of shallow sandy shores in the lower reaches of Victoria Creek. Shown are data from 3 transects; (a) 12/11/03b, (b) 6/1/04a, and (c) 30/1/04b (Table 1) 
Table 1. Platycephalus spp. Density, size and depth distribution along shallow sandy habitats in the lower reaches of tropical estuaries in northeastern Australia, as determined by visual census. $10 \mathrm{~m}$ max. density: maximum density observed within a $10 \mathrm{~m}$ section of the transect. Actual number of individuals observed in the density maximum is shown in parantheses. Biomass was estimated from length-weight relationship of $P$. fuscus $100-442 \mathrm{~mm}$ TL examined for dietary analysis (Baker \& Sheaves 2005). The average density and biomass values in parantheses at the bottom of the table were calculated only from the 14 transects with good visibility (shown in table) and do not include data from the remaining 25 transects with poor visibility (see 'Materials and methods')

\begin{tabular}{|c|c|c|c|c|c|c|c|c|c|}
\hline Location & $\begin{array}{l}\text { Date } \\
\text { code }\end{array}$ & $\begin{array}{l}\text { Transect } \\
\text { length }(\mathrm{m})\end{array}$ & $\begin{array}{c}\text { Area } \\
\left(\mathrm{m}^{2}\right)\end{array}$ & No. flathead & $\begin{array}{c}\text { Density } \\
\left(\text { no. }^{-2}\right)\end{array}$ & $\begin{array}{c}\text { Biomass } \\
\left(\mathrm{g} \mathrm{m}^{-2}\right)\end{array}$ & $\begin{array}{l}10 \text { m max. } \\
\text { density }(n)\end{array}$ & $\begin{array}{l}\mathrm{TL}(\mathrm{mm}) \\
\text { range }\end{array}$ & $\begin{array}{l}\text { Depth } \\
\text { range }(\mathrm{m})\end{array}$ \\
\hline Ross & $240703 a$ & 10 & 30 & 1 & 0.0333 & 36.71 & $0.0330(1)$ & 550 & 0.04 \\
\hline Victoria & $121103 a$ & 375 & 1125 & 24 & 0.0213 & 5.80 & $0.3000(9)$ & $100-500$ & $0.04-0.50$ \\
\hline Victoria & $121103 b$ & 240 & 720 & 34 & 0.0472 & 8.25 & $0.7667(23)$ & $120-400$ & $0.06-0.40$ \\
\hline Victoria & $060104 \mathrm{a}$ & 150 & 450 & 48 & 0.1067 & 22.78 & $0.6667(20)$ & $130-500$ & $0.10-0.60$ \\
\hline Victoria & 060104b & 200 & 600 & 17 & 0.0283 & 4.67 & $0.1667(5)$ & $180-400$ & $0.17-0.60$ \\
\hline Victoria & 060104c & 130 & 390 & 13 & 0.0333 & 7.61 & $0.2000(6)$ & $160-420$ & $0.20-0.60$ \\
\hline Victoria & $300104 a$ & 120 & 360 & 18 & 0.0500 & 8.13 & $0.2000(6)$ & $140-420$ & $0.08-0.58$ \\
\hline Victoria & $300104 b$ & 120 & 360 & 71 & 0.1972 & 46.16 & $0.8667(26)$ & $140-500$ & $0.02-0.55$ \\
\hline Herbert & $280504 a$ & 250 & 750 & 2 & 0.0027 & 0.12 & $0.0330(1)$ & $200-200$ & $0.08-0.12$ \\
\hline Herbert & $280504 b$ & 131 & 393 & 5 & 0.0127 & 5.98 & $0.1000(3)$ & $160-550$ & $0.10-0.50$ \\
\hline Herbert & $140704 \mathrm{~h}$ & 416 & 1248 & 11 & 0.0088 & 2.60 & 0.1667 (5) & $180-570$ & $0.05-0.30$ \\
\hline Herbert & $140704 \mathrm{i}$ & 250 & 750 & 4 & 0.0053 & 0.59 & $0.0667(2)$ & $100-350$ & $0.03-0.40$ \\
\hline Victoria & $150704 a$ & 185 & 555 & 25 & 0.0450 & 9.89 & $0.2333(7)$ & $200-450$ & $0.20-0.62$ \\
\hline Herbert & $120804 \mathrm{e}$ & 386 & 1158 & 8 & 0.0069 & 2.53 & $0.1000(3)$ & $250-600$ & $0.10-0.30$ \\
\hline Total (average) & 39 transects & s 9036 & & 296 & $(0.0428)$ & (11.56) & & $100-600$ & $0.02-0.62$ \\
\hline
\end{tabular}

tiles. This means there was no significant relationship between flathead size and the minimum water depth occupied among the individuals surveyed.

The shallowest individuals were stationed in water approximately equal to the body depth of the largest prey they could consume (Fig. 3). To relate the minimum observed depth of flathead to their prey, the

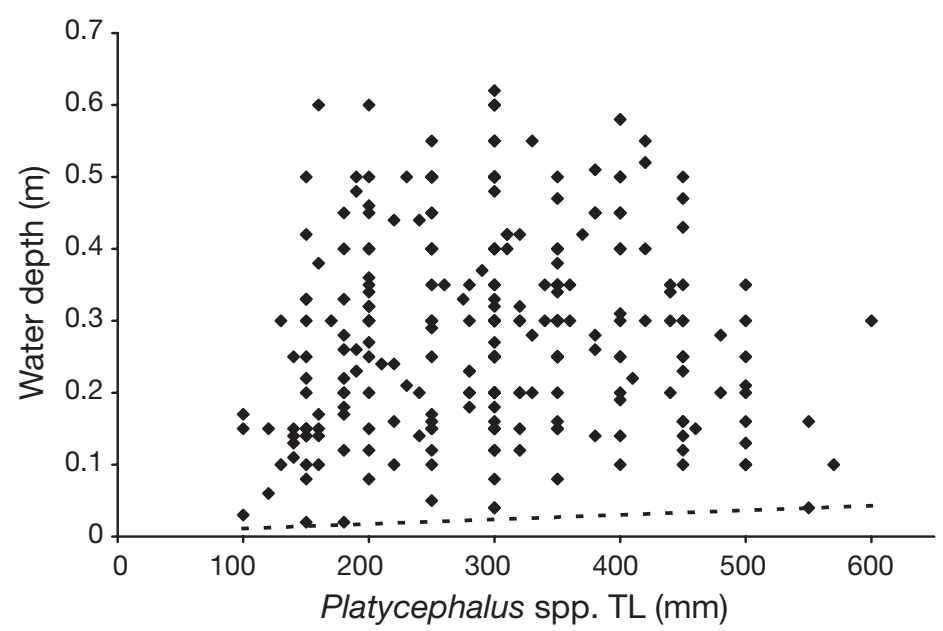

Fig. 3. Platycephalus spp. Size-related depth distribution of flathead $(n=296)$ along shallow sandy banks in the lower reaches of tropical estuaries. Dashed line represents 99th quantile of predator size-prey body depth relationship for P. fuscus (adapted from Baker \& Sheaves 2005). A data point on the line indicates a predator in water of depth equal to the body depth of the largest prey eaten predator length-prey length relationship for Platycephalus fuscus determined by Baker \& Sheaves (2005) was converted to a predator length-prey body depth relationship for the 3 deepest-bodied taxa, Leiognathus spp., Ambassis telkara and Gerres filamentosus. By using the deepest-bodied prey taxa, the upper boundary of the relationship (99th quantile regression; Scharf et al. 1998) indicates the maximum body depth of prey consumed across the size range of flathead. When superimposed onto the flathead depth distribution (dashed line in Fig. 3), it can be seen that flathead can access water as shallow as the body depth of the largest prey they could consume.

On average (based on the 9 transects in which $\geq 10$ flathead were sighted), the greatest densities of flathead were stationed in water between 0.2 and $0.4 \mathrm{~m}$ deep (Fig. 4). For one transect the greatest density was sighted between 0.4 and $0.5 \mathrm{~m}$ depth, and in another it was between 0.5 and $0.6 \mathrm{~m}$ depth indicating that the density maximum in $<0.4 \mathrm{~m}$ of water was not due to observer bias under-representing fish in deeper waters.

\section{DISCUSSION}

Only 14 of the 39 transects were considered reliable for providing quantitative density estimates, and only 1 group of piscivores (platycephalids) were found in the transects. Despite this, the high densities and biomasses recorded suggest the densities and biomasses of large 


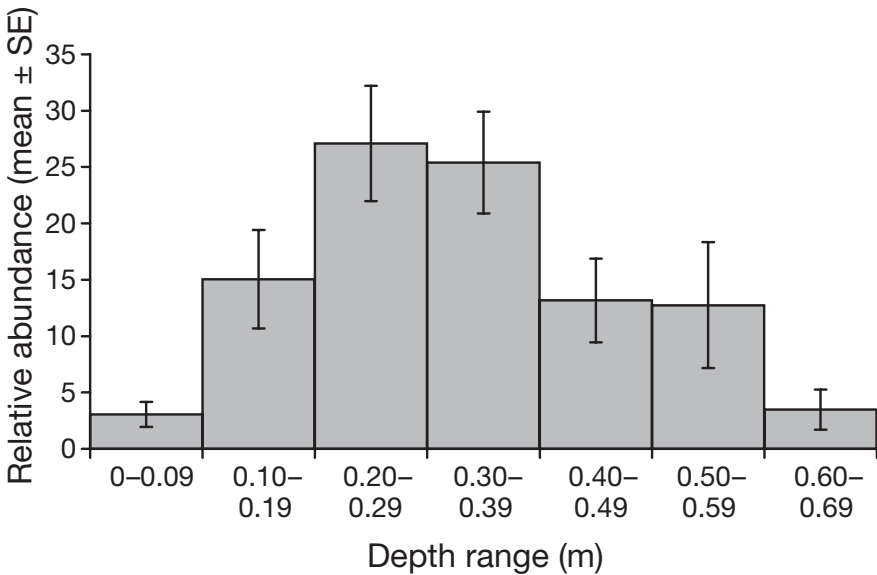

Fig. 4. Platycephalus spp. Depth distribution of flathead $\geq 100 \mathrm{~mm}$ TL observed during visual surveys along shallow sandy shores in tropical estuaries of northeastern Australia. Includes only transects in which $\geq 10$ individuals were sighted $(n=9)$. Error bars: \pm SE

( $\geq 100 \mathrm{~mm}$ ) piscivorous fishes in shallow tropical estuarine habitats may previously have been underestimated by up to several orders of magnitude. The minimum transect-specific density $\left(0.0027 \mathrm{~m}^{-2}\right)$ was approximately equal to the maximum density of flathead reported from seine net samples encompassing the same estuaries $\left(0.0029 \mathrm{~m}^{-2}\right.$, Sheaves 2001$)$, while the maximum density in this study $\left(0.1972 \mathrm{~m}^{-2}\right)$ was 2 orders of magnitude greater than that from seine net samples. Furthermore, the number of flathead seen in $10 \mathrm{~m}$ sections of several transects during the present study ( $\geq 20$ ind.) exceeds the total sample size of Platycephalus spp. reported from other tropical Indo-West Pacific estuaries sampled using a range of gears including seine nets, gill nets and beam trawls (Blaber et al. 1989, Blaber \& Milton 1990, Haywood et al. 1998, Salini et al. 1998).

The maximum density (0.1972 ind. $\mathrm{m}^{-2}$ ) and average biomass $\left(11.56 \mathrm{~g} \mathrm{~m}^{-2}\right)$ estimates of large flathead in shallow waters in this study are equivalent to estimates of entire fish assemblages gained from block netting shallow water estuarine habitats around the world (Table 2). While the average density observed in the present study $\left(0.0435\right.$ ind. $\left.\mathrm{m}^{-2}\right)$ is 1 or 2 orders of magnitude lower than the densities listed in Table 2, the other studies sampled entire fish assemblages covering many trophic groups, while the present study estimated density of only one group of large piscivores. For example, Morton (1990) reported average densities and biomass of 0.27 ind. $\mathrm{m}^{-2}$ and $25.3 \mathrm{~g} \mathrm{~m}^{-2}$ for the fish assemblage of intertidal mangrove habitat in subtropical Moreton Bay, Australia (Table 2). This is amongst the highest recorded biomass of teleost fishes for estuarine habitats (Morton 1990, Barletta et al. 2003) and comprises an assemblage of at least $40 \mathrm{spp}$. Given that the combined top-level predators (5 spp.) collected by Morton (1990) contributed 0.002 ind. $\mathrm{m}^{-2}$ and $0.3 \mathrm{~g} \mathrm{~m}^{-2}$ to the total sample (Table 2), the average density and biomass of top-level predators observed in shallow waters during the present study are very high by global standards.

The common prey fishes consumed by Platycephalus spp. (Baker \& Sheaves 2005) have a strong affinity for

Table 2. Density and biomass estimates of fish assemblages of shallow estuarine habitats sampled with block nets or visual census. QLD: Queensland. Table adapted from Barletta et al. (2003) and Morton (1990)

\begin{tabular}{|c|c|c|c|c|c|c|}
\hline Location & Habitat & $\begin{array}{l}\text { Sampling } \\
\text { gear }\end{array}$ & No. spp. & $\begin{array}{l}\text { Density } \\
\text { (ind. } \mathrm{m}^{-2} \text { ) }\end{array}$ & $\begin{array}{l}\text { Biomass } \\
\left(\mathrm{g} \mathrm{m}^{-2}\right)\end{array}$ & Source \\
\hline \multicolumn{7}{|l|}{ Australia } \\
\hline North QLD (various) & $\begin{array}{l}\text { Shallow sandy } \\
\text { shore }\end{array}$ & Visual census & $\leq 3$ & 0.04 & 11.6 & This study \\
\hline North QLD - Embley Estuary & Intertidal creek & $\begin{array}{l}\text { Block net } \\
\text { and rotenone }\end{array}$ & 66 & - & 8.2 & Blaber et al. (1989) \\
\hline \multicolumn{7}{|l|}{ SE QLD - Moreton Bay } \\
\hline Total assemblage & Mangrove forest & Block net & 40 & 0.27 & 25.3 & Morton (1990) \\
\hline Primary predators & Mangrove forest & Block net & 5 & 0.002 & 0.3 & Morton (1990) \\
\hline New South Wales & Tidal creek & Block net & 46 & 0.94 & 6.4 & Bell et al. (1984) \\
\hline Solomon Islands & $\begin{array}{l}\text { Intertidal creeks } \\
\text { and forest? }\end{array}$ & $\begin{array}{l}\text { Block net and } \\
\text { rotenone }\end{array}$ & 85 & - & 11.6 & Blaber \& Milton (1990) \\
\hline Brazil - Caete Estuary & Tidal creek & Block net & 49 & 0.11 & 2.1 & Barletta et al. (2003) \\
\hline USA Florida - Everglades & $\begin{array}{l}\text { Prop root/ } \\
\text { mangrove forest }\end{array}$ & Block net & 64 & 8.0 & 15.0 & Thayer et al. (1987) \\
\hline South Africa & Intertidal marsh & Block net & 41 & 1.5 & 2.4 & $\begin{array}{l}\text { Paterson \& } \\
\text { Whitfield (1996) }\end{array}$ \\
\hline
\end{tabular}


waters less than $0.75 \mathrm{~m}$ deep (R. Johnston unpubl. data). Fresh prey fish in the stomachs of flathead collected throughout the day from these shallow habitats (Baker \& Sheaves 2005) suggests that flathead feed actively in these habitats during daylight hours. The minimum depth occupied by flathead is equivalent to the body depth of the largest prey consumed (Fig. 3). These shallowest-stationed flathead were generally within 1 to $10 \mathrm{~cm}$ of the shoreline. While the observed depth distribution of flathead is unlikely to be directly related to the body depth of the prey fishes examined, it is clear that the largest prey consumed by flathead can not physically access waters shallow enough to exclude their flathead predators. Furthermore, it seems unlikely that the narrow strip of shallow water between the shallowest flathead and the shoreline would provide a useful refuge habitat for smaller fishes, as few estuarine fishes in the region utilise this extreme edge habitat (R. Johnston unpubl. data).

Platycephalus spp. are just one group of a diverse piscivore assemblage recorded from shallow estuarine nurseries (Baker \& Sheaves 2005) and the depth distribution of these alone does not determine the predation potential within these habitats. The flounder, Pseudorhombus arsius (Pleuronectidae), is another common shallow-water specialist piscivore (Baker \& Sheaves 2005, Sheaves 2006). The lack of sightings of P. arsius during visual surveys is probably because individuals either do not spook as easily or are not as visible when spooked as flathead, rather than an indication of their absence from shallow waters. Similarly, carangids $>100 \mathrm{~mm}$ are commonly captured when angling in these areas (Baker \& Sheaves 2005) but none were observed in the transects. On coral reefs, during occasional, brief visits mobile carangids exert predation mortality equal to or greater than resident piscivores on other reef fishes (Hixon \& Carr 1997). Although not sighted within the transects, our observations and those of other authors (Blaber et al. 1985) show larger mobile predators periodically enter shallow waters to feed, exhibiting a similar pattern of predation to that on coral reefs. Such predation events by mobile predators may be unpredictable and irregular (Hixon \& Carr 1997), but assuming they are insignificant may lead to erroneous or overly simplified conclusions about the importance of predation in structuring these communities (Edwards et al. 1982).

The spatial extent of the present study is limited, with most of the successful transects conducted at Victoria Creek $(n=8)$ and Herbert River $(n=5)$ (Table 1). We suggest, however, that similar densities of flathead occur in such habitats throughout the region. Large numbers of flathead were regularly seen in transects where poor visibility and the risk of attack by crocodiles precluded formal density estimates. Additionally, densities of Platycephalus spp. in seine net samples from 8 nearby estuaries were consistently comparable to or greater than those recorded in seine nets from Victoria Creek (Sheaves 2006).

The present study suggests that a significant component of the predator assemblage in shallow tropical estuarine habitats may previously have been considerably underestimated due to sampling biases. A similar conclusion was made for a much studied New Jersey (USA) estuary when a novel sampling approach (nighttime sampling) was employed (Rountree \& Able 1997). This led to the hypothesis that shallow water habitats in Mid-Atlantic Bight estuaries, and elsewhere in the world, may not provide young-of-the-year fishes with the level of predator refuge previously assumed. Even with information on the abundance of piscivores, the relative refuge value of shallow water habitats remains unclear because few studies (including this one) have been able to examine the abundance of piscivores in shallow and adjacent deeper habitats in a comparable way. Furthermore, the relative density of predators in various habitats does not necessarily reflect predation pressure (Abrams 1993, Sheaves 2001). Ultimately comparisons of the relative predation pressure across the depth range are needed to address the shallow water refuge hypothesis.

Acknowledgements. We thank T. Hatley, T. Prior, T. Cornish and K. Abrantes for their assistance in the field. This project was funded by the Cooperative Research Centre for Coastal Zone, Estuary and Waterway Management (Coastal CRC).

\section{LITERATURE CITED}

Abrams PA (1993) Why predation rate should not be proportional to predator density. Ecology 74:726-733

Baker R, Sheaves M (2005) Redefining the piscivore assemblage of shallow estuarine nursery habitats. Mar Ecol Prog Ser 291:197-213

Barletta M, Barletta-Bergan A, Saint-Paul U, Hubold G (2003) Seasonal changes in density, biomass and diversity of estuarine fishes in tidal mangrove creeks of the lower Caete Estuary (northern Brazilian coast, east Amazon). Mar Ecol Prog Ser 256:217-228

Beck M, Heck K, Able K, Childers D and 9 others (2001) The identification, conservation, and management of estuarine and marine nurseries for fish and invertebrates. Bioscience 51:633-641

Bell JD, Pollard DA, Burchmore BC, Pease BC, Middleton MJ (1984) Structure of a fish community in a temperate tidal mangrove creek in Botany Bay, New South Wales. Aust J Mar Freshw Res 35:33-46

Blaber SJM (1980) Fish of the Trinity Inlet system of north Queensland with notes on the ecology of fish faunas of tropical Indo-Pacific estuaries. Aust J Mar Freshw Res 31: 137-146

Blaber SJM, Blaber TG (1980) Factors affecting the distribution of juvenile estuarine and inshore fish. J Fish Biol 17: 143-162

Blaber SJM, Milton DA (1990) Species composition, commu- 
nity structure and zoogeography of fishes of mangrove estuaries in the Solomon Islands. Mar Biol 105:259-267

Blaber SJM, Young JW, Dunning MC (1985) Community structure and zoogeographic affinities of the coastal fishes of the Dampier region of north-western Australia. Aust J Mar Freshw Res 36:247-266

Blaber SJM, Brewer DT, Salini JP (1989) Species composition and biomasses of fishes in different habitats of a tropical northern Australian estuary: their occurrence in the adjoining sea and estuarine dependence. Estuar Coast Shelf Sci 29:509-531

Boesch D, Turner RE (1984) Dependence of fishery species on salt marshes: the role of food and refuge. Estuaries 7: 460-468

Coles RG, Lee Long WJ, Squire BA, Squire LC, Bibby JM (1987) Distribution of seagrasses and associated juvenile commercial penaeid prawns in north-eastern Queensland waters. Aust J Mar Freshw Res 38:103-119

Coles RG, Lee Long WJ, Watson RA, Derbyshire KJ (1993) Dsitribution of seagrasses and their fish and penaeid prawn communities in Cairns Harbour, a tropical estuary, northern Queensland, Australia. Aust J Mar Freshw Res 44:193-210

Douglas WA, Lanzing WJR (1981) The respiratory mechanisms of the dusky flathead, Platycephalus fuscus (Platycephalidae, Scorpaeniformes). J Fish Biol 18:545-552

Edwards DC, Conover DO, Sutter F (1982) Mobile predators and the structure of marine intertidal communities. Ecology 63:1175-1180

Gould WW (1992) Quantile regression with bootstrapped standard errors. Stata Tech Bull 9:19-21

Haywood MDE, Heales DS, Kenyon RA, Loneragan NR, Vance DJ (1998) Predation of juvenile tiger prawns in a tropical Australian estuary. Mar Ecol Prog Ser 162:201-214

Hindell JS, Jenkins GP, Keough MJ (2000) Variability in the abundances of fishes associated with seagrass habitats in relation to diets of predatory fishes. Mar Biol 136:725-737

Hindell JS, Jenkins GP, Keough MJ (2001) Spatial and temporal variability in the effects of predation on macrofauna in relation to habitat complexity and cage effects. Mar Ecol Prog Ser 224:231-250

Hixon MA, Carr MH (1997) Synergistic predation, density dependence, and population regulation in marine fish. Science 277:946-949

Laegdsgaard P, Johnson CR (1995) Mangrove habitats as nurseries: Unique assemblages of juvenile fish in subtropical mangroves in eastern Australia. Mar Ecol Prog Ser 126: $67-81$

McIvor CC, Odum WE (1988) Food, predation risk, and micro-

Editorial responsibility: Otto Kinne (Editor-in-Chief), Oldendorf/Luhe, Germany habitat selection in a marsh fish assemblage. Ecology 69: 1341-1351

Morton RM (1990) Community structure, density and standing crop of fishes in a subtropical Australian mangrove area. Mar Biol 105:385-394

Paterson AW, Whitfield AK (1996) The fishes associated with an intertidal salt marsh creek in the Kariega Estuary, South Africa. Trans R Soc S Afr 51:195-218

Paterson AW, Whitfield AK (2000) Do shallow-water habitats function as refugia for juvenile fishes? Estuar Coast Shelf Sci 51:359-364

Rountree RA, Able KW (1997) Nocturnal fish use of a New Jersey marsh creek and adjacent bay shoal habitats. Estuar Coast Shelf Sci 44:703-711

Rozas LP, Hackney CT (1983) The importance of oligohaline estuarine wetland habitats to fisheries resources. Wetlands 3:77-89

Ruiz GM, Hines AH, Posey MH (1993) Shallow water as a refuge habitat for fish and crustaceans in non-vegetated estuaries: an example from Chesapeake Bay. Mar Ecol Prog Ser 99:1-16

Salini JP, Brewer DT, Blaber SJM (1998) Dietary studies on the predatory fishes of the Norman River Estuary, with particular reference to penaeid prawns. Estuar Coast Shelf Sci 46:837-847

Scharf FS, Juanes F, Sutherland M (1998) Inferring ecological relationships from the edges of scatter diagrams: comparison of regression techniques. Ecology 79:448-460

Sheaves M (2001) Are there really few piscivorous fishes in shallow estuarine habitats? Mar Ecol Prog Ser 222:279-290

Sheaves M (2005) Nature and consequences of biological connectivity in mangrove systems. Mar Ecol Prog Ser 302: 293-305

Sheaves M (2006) Scale dependent variation in composition of fish fauna among sandy tropical estuarine embayments. Mar Ecol Prog Ser 310:173-184

Sheaves M, Molony B (2000) Short-circuit in the mangrove food chain. Mar Ecol Prog Ser 199:97-109

Shenker JM, Dean JM (1979) The utilization of an intertidal salt marsh creek by larval and juvenile fishes: abundance, diversity and temporal variation. Estuaries 2:154-163

Smith TM, Hindell JS (2005) Assessing effects of diel period, gear selectivity and predation on patterns of microhabitat use by fish in a mangrove dominated system in SE Australia. Mar Ecol Prog Ser 294:257-270

Thayer GW, Colby DR, Hettler WF Jr. (1987) Utilization of the red mangrove prop root habitat by fishes in South Florida. Mar Ecol Prog Ser 35:25-38

Zar JH (1999) Biostatistical analysis, 4th edn. Prentice Hall International, Sydney

Submitted: August 11, 2005; Accepted: March 30, 2006

Proofs received from author(s): September 13, 2006 